\title{
The Implementation of Policy on Appointment of Permanent Lecturers at Private Universities in the City and Regency of Cirebon
}

\author{
Nursahidin ${ }^{1}$, Soleh Suryadi ${ }^{2}$, Ali Anwar Yusuf ${ }^{3}$ \\ Universitas Pasundan, Indonesia \\ nursahidin54@gmail.com
}

\begin{abstract}
The focus of this research is the implementation of policy on the appointment of permanent lecturers at private universities in the City and Regency of Cirebon which are not optimal yet,so that Private Universities in the City and Regency of Cirebon are faced with various problems in the appointment of permanent lecturers, that is, they have not yet fully paid attention to the regulations and quality standards of lecturers. The sub focus of this research is application of the approach of the idealized policy, the implementing organization, the target group and environmental factors as dimensions of policy implementation in relation to the appointment of permanent lecturers at private universities in the City and Regency of Cirebon.Based on the problem statement set out at the focus of research, then downgraded into a research question, what are the factors that have caused the implementation of policy on the appointment of the permanent lecturers at Private Universities in Cirebon City and Regency to be not yet optimal? What efforts are made by private universities in the city and regency of Cirebon to appoint permanent lecturers?And what strategies are effective to optimize the implementation of the policy of appointment of the permanent lecturers at Private Universities in the City and Regency of Cirebon?The results of the researchthen further analyzed with the theory of organizational effectiveness with the criteria of production, efficiency, satisfaction, adaptation and development. The method used in the research is a qualitative research method. Qualitative data collection is done through observation, interviews and Focus Group Discussion (FGD). In this research the writers describe the phenomena found in the field related to the research problem, then analyze it but without calculating the effect of a variable to other variables. Through this qualitative research method, it is expected that the writers can obtain accurate data related to the problem under research, so that the writers can analyze it in depth on how to implement the policy of appointment of permanent lecturers at PTS (Private Universities) in the City and Regency of Cirebon. The results showed the findings in the form of developing theories that strengthen the concept of Smith's policy implementation process (1973) that optimizing the appointment of permanent lecturers at Private Universities in the City and Regency of Cirebon can be achieved if Organizational Culture, Motivation and Competitiveness are developed.
\end{abstract}

Keywords: Implementation, idealized policy, the implementing organization, the target group, environmental factors, and organizational effectiveness.

\section{INTRODUCTION}

Efforts to educate the life of the nation which is the goal of the Indonesian State as stated in the Opening of the 1945 Constitution,among them are through higher education processes,namely "education levels after secondary education which include diplomas, scholars, master's programs, doctoral programs, and professional programs, as well as specialist programs organized by universities based on Indonesian culture" (Law Number 12 of 
2012).And those who have the task to educate the nation's life through the transformation of science in higher education are lecturers.According to Law Number 14 of 2005 the lecturer is "professional educators and scientists with the main task of transforming, developing and disseminating science, technology and arts through education, research, and community service "(Law No. 14 of 2005).

The Law number 4 of 2014 states that Universities which include State Universities, State Universities Legal Entities, and Private Universities have the autonomy to manage their own institutions as centers for organizing Universities Tridharma.Autonomy referred to consists of academic autonomy (including the determination of morale and operational policies and the implementation of education, research, and community service)and nonacademicautonomy (including the determination of norms and operatioanal policies as well as financial, student, employment and infrastructure organizations).Furthermore, it is also mentioned that management autonomy in State Universities is regulated by the Implementing Agency in accordance with statutory regulations.

The appointment of lecturers at private universities is carried out in various conditions, namely:1) to fulfill the minimum requirements for the number of lecturers, 2) to fulfill the lecturer / student ratio,3) to strengthen human-lecturer resources in order to improve the quality of education and increase the value and level of accreditation both in the accreditation of study programs and accreditation of institutions.

Some of the problems that exist in Private Universities in the City and Regency of Cirebon are:1) there are still several study programs where the number of permanent lecturers does not fulfill the minimum number,and 2) there are still several study programs where lecturer / student ratio is not ideal, does not fulfill the requirements, namely for the Natural Science groups 1: 30 and the Social Sciences groups 1: 45 group.

The causes of these problems are:1) Certain Study Programs such as engineering, health and maritime having difficulties in finding lecturers or prospective lecturers who have competencies that match with the Study Program,especially lecturers who are linear in their Undergraduate and Postgraduate levels of education, even there are still study programs that have the highest level of Diploma IV or Bachelor degree, there is no Postgraduate, so it cannot be forced to appoint lecturers with linear Bachelor and Master level education.2) The number of students entering private universities is not fixed,2) The number of students entering private universities is not fixed,sometimes up and down, this kind of conditions greatly affect the lecturer / student ratio and ultimately impact on the budget of the institution. This condition becomes a consideration for Private Universities in the appointment of permanent lecturers. 
Based on the facts above, Private Universities in the City and Regency of Cirebon are faced with the process of policy implementation, namely the process of implementation of policy on appointing permanent lecturers.

The aims of this research are: 1) to find out the factors that caused the implementation of the Permanent Lecturer appointment policy have not optimal yet,2) to find out the efforts made in the appointment of Permanent Lecturers, and 3) to find out an effective strategy in optimizing the implementation of the policy implementation on the appointment of Permanent Lecturers at Private Universities in the City and Regency of Cirebon.

\section{RESEARCH METHOD}

The research method used is a qualitative method.Bogdan and Taylor in Moleong (2009: 4) said that qualitative methodology is a research procedure that produces descriptive data in the form of written or oral words from people and observed behavior.

Qualitative research is a methodto explore and understand the meaning that - by a number of individuals or groups of people -ascribedto social or humanitarian problems. The qualitative research process involves important efforts, such as asking questions and procedures, collecting specific data from participants, analyzing data inductively starting from specific themes to general themes, and interpreting the meaning of data (Creswell,2014)

Data collection techniques are done through observation, which is data collection by conducting observations directly on the object of research,in depthinterviewsconducted individually and in the form of Focus Group Discussion (FGD), and documentation studies that study and analyze data from various written documents related to the problem under research. While the data analysis is carried out by using qualitative data analysis techniques by analyzing in-depth descriptive data in the form of oral and written information from the informant, as well as facts and symptoms from the observations.According to Miles and Huberman (1992), explained that qualitative data analysis consists of three activities that occur simultaneously, they are: data reduction, data presentation and verification and drawing conclusions.

The formulation of the strategy in this study uses a SWOT analysis that is an analysis of the factors of Strength, Weakness, Opportunity, and Threat faced by the organization.Rangkuti (2015), said that the SWOT analysis is various identification of various systematicfactors to formulate a corporate / organizational strategy. This analysis is based on logic which can maximize Strength and Opportunity, but simultaneously minimize

Weakness and Threat.SWOT analysis compares between external factors namely Opportunity and Threats with internal factors namely Strength and Weakness. 


\section{THEORITICAL REVIEW}

Implementation comes from the word implementation, which means implementation (execution). Thus, the implementation of public policy is the implementation of a public policy.Policy implementation according to the Webster Dictionary (Merriam-Webster Dictionary) shortly formulates that to implement means to provide the means for carrying out; (providing the means to do something); to give practical effect to (cause an impact or effect on something).

The public policy implementation is an integral part of the public policy process.This was confirmed by Anderson (1979) said that public policy consists of five processes, namely: 1) problem formulation, 2) formulation, 3) adoption, 4) implementation, 5) evaluation.Based on the opinion above, one of the processes of public policy is the implementation of policies. The questions in the implementation of policies among others are who are involved in policy implementation?What are they working on? What is the impact of the policy content?

Van Mater and Van Horn (1975), formulated the implementation process as "Those actions by public or private individuals (or groups) that are derected at the achievment of goals and objectives set in prior policy decisions."The statement gives the meaning that the implementation of the policy are actions carried out by individuals or officials or groups of government and private sector, which are directed at the planning of goals and objectives which are the priority in policy decisions.Some factors that are believed to influence the implementation of policy are: 1) Standards and objectives of policy, 2) Resources, 3) Communication between implementing agencies, 4) Characteristics of implementing agencies, 5) Social, economic and political environment, 6) Implementing attitudes.

Smith (1973) stated that public policy is used as a force that can reduce tensions which exist in society.Therefore it is important to apply the relevant policy context.Furthermore, Smith also identified four important components in the policy implementation process, namely: "... I wish to identify four such components which are important in the policy implementation process: (1) the idealized policy,(2)the implementing organization, (3) the target group, and (4) environmental factors".

Furthermore, in achieving organizational goals and objectives in order to be achieved more effectively, the leadership of the organization must be able to influence the effectiveness of individuals, groups and organizations (Gibson, 1993).The effectiveness of the individual emphasizes the implementation of the work of the worker or member of the organization.The effectiveness of a group is the sum of donations from all its members.And effectiveness of the organization is a function of the effectiveness of individuals and groups.The relationship between the three perspectives on 
effectiveness shows that the effectiveness of the group depends on the effectiveness of the individual, and the effectiveness of the organization depends on the effectiveness of the group.

John M. Ivancevich (2006) concludes that: (1) effectiveness criteria must reflect the entire input-output-process cycle, not just output,and (2) the effectiveness criteria must reflect the relationship between the organization and its external environment."Organizational effectiveness is a comprehensive concept that includes a number of component concepts"

Stephen P. Robbin (1994) delivered 4 (four) organizational effectiveness approaches, namely: 1) Goal Attainment Approach, 2) System Approach, 3) Strategic-Constituencies Approach, 4) CompetingValues Approach.While Gibson (1993) explained the five criteria of effectiveness, namely: 1) Production, 2) Efficiency, 3) Satisfaction, 4) Adaptation, 5) Develompment.

\section{RESULT AND DISCUSSION}

The theoretical approach used in this study is the theory of Thomas B. Smith (1973), because Smith views that there are four important components in the process of policy implementation, namely:1) idealized policy,2) the implementing organization, 3) the target group and 4) environmental factors.

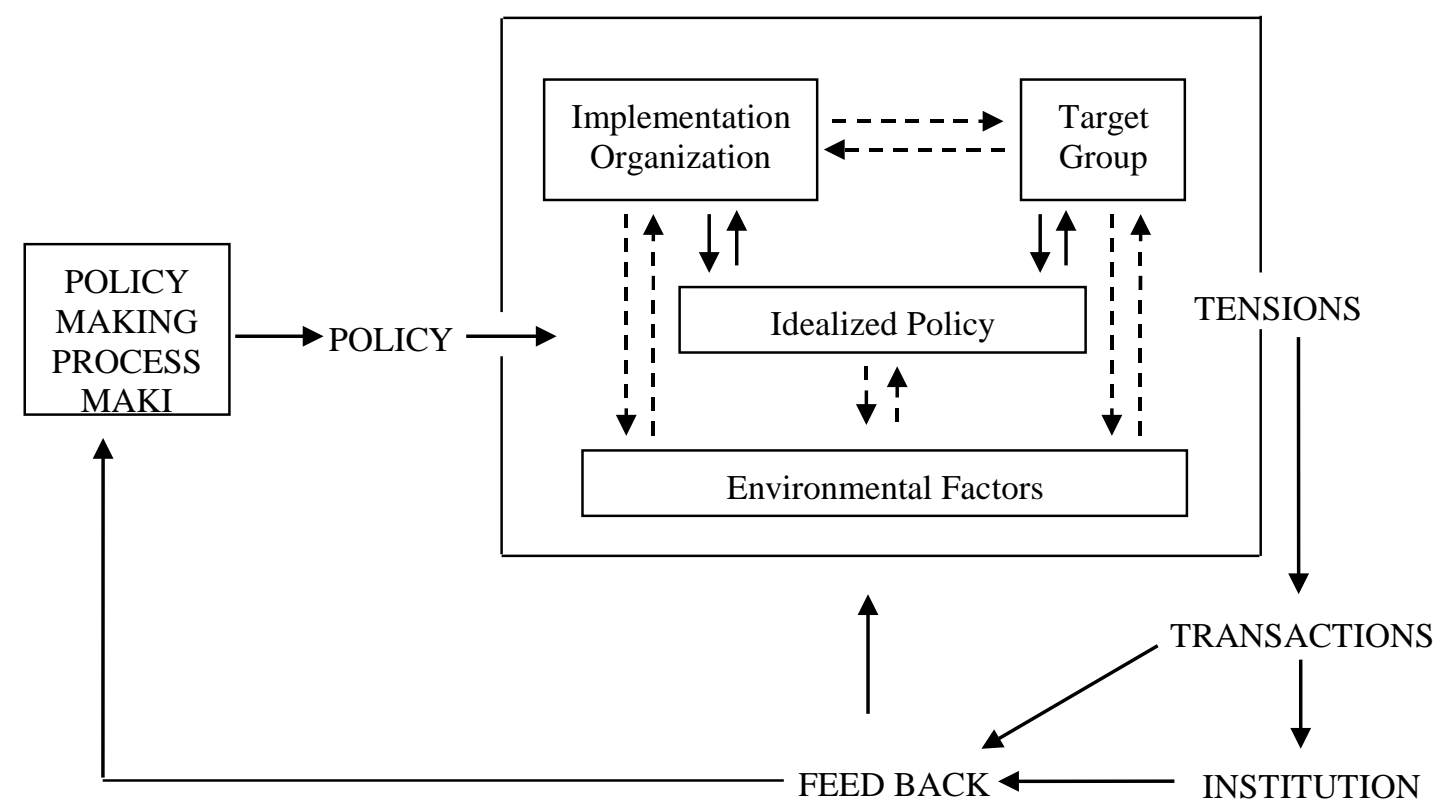

Figure1

The Policy Implementation Process Model from Smith

The model illustrates the main core of the policy implementation process.When policies are implemented, interactions within and between 
components of a policy application system create differences and tensions. The tensions that arise relating to the goals and objectives of the policy.This pattern of transactions may be or may be not lead to the institution (institution).Feedback is brought back into the matrix of causes of tension from transaction patterns and institutions.

\section{Factors That Cause the Implementation of Policy on Appointment of Permanent Lecturers at Private Universities (PTS) in Cirebon City and Regencynot Optimal Yet}

There are four important components in the process of implementing policies, namely: 1) idealized policy, 2) the implementing organization, 3) the target group and 4) environmental factor. 1) Idealized Policy

An ideal policy is defined as an ideal pattern of interaction that policy makers try to carry, which in this case apolicy is made by the Government regarding the appointment of permanent lecturers at PTS (Private Universities).

There are four categories of variables that are relevant in an ideal policy, namely (1) The Formal policy;it is formal, legal decisions, which the government tries to implement.(2) The type of policy with the three types of policy categories, namely:a) policies may be complex or they may be simple in nature, Policies may berequire the modification (or the establishment) policies for change (development) within the organization or outside the organization,c) policies also may be classified as distributive, re-distributive, regulatory, self-regulatory, or emotive-symbolic(3) The program consists of three aspects, namely: a) Intensity of support.The level of support the government provides to the implementation of policies.b) The source ofpolicy.Is the policy needed to meet the needs and demands of the community, or is it designed with little demand and support?c) The scope,is the policy extensive and comprehensive in scope, or is it focused in a narrow geographical scope and subject area?(4) The images of the policy. It is important to consider the image that is produced by policy in the community.

TheFormal Policy, the government formally issued a policy regarding the appointment of permanent lecturers at private universities, also regulating the minimum number of permanent lecturers and lecturer / student ratio.Private Universities in the City and Regency of Cirebon have implemented a policy of appointment of permanent PTS lecturers in accordance with government regulations, whether it is the policy of fulfilling the minimum number of lecturers for each study program that is 5 (five) people, as well as the fulfillment of the number of lecturers to fit the ideal ratio which is 1:30 for the Natural Sciences program and 1: 45 for the Social Sciences program with the lecturer status of the National Lecturer Identification Number (NIDN) and Special Lecturer Identification Number (NIDK). 
However, even though PTS has fulfilled lecturers, in its implementation it has not yet fully carried out other stipulated provisions, among them are not yet fulfilled linear qualified Bachelor and Master lecturers because for certain study programs the highest levels are only up to the Bachelor level, there are no Masters,such as the Physiotherapy, Radiology, Nautica, and Engineering Study Programs. Then about the rights and obligations of permanent PTS lecturers has not been fulfilled, there are PTS that have not provided a decent income above the minimum living needs among them, so that there are still lecturers who have not fulfilled the obligation to work fully because they serve as employees in other institutions or other businesses.

The Type of Policy, there are three types of policies in the policy implementation process, namely:a)Policies may be complex or they may be simple in nature, b) Policies may be require the modification (or the establishment)policies to change (development) within the organization or outside the organization,c) Policies also may be classified as distributive, redistributive, regulatory, self-regulatory, or emotive-symbolic

Policies may be complex or they may be simple in nature,the implementation of policy is a crucial stage in the public policy process.A policy program must be implemented so that it has the desired impact or objectives.But in the order of implementation it is always faced with problems because in implementing a policy is always associated with the target group and the bureaucrats themselves, with their respective complexity.Therefore, eventhough the policy with clear objectives have been issued but face problems of implementation (not or can not be implemented yet) because faced with various difficulties or obstacles.

Likewise in implementing the policy of permanent lecturer appointment at PTS in the City and Regency of Cirebon, not all PTS implements the policy easily and smoothly but there are PTS facing various difficulties and obstacles. One of the obstacles faced by PTS in the City and Regency of Cirebon is the number of students in PTS is sometimes fluctuating, sometimes decreases and sometimes increases, when the number of students rises, the number of lecturers must also increase, so that PTS must appoint permanent lecturers to fulfill the lecturer / student ratio.The problem is that when the number of study programs decreases while the number of students is already large, then the study program will have an overage of permanent lecturers.This has an impact on PTS institutions and also on permanent lecturers, especially on budget and financial issues, the PTS income budget will be reduced automatically because of the number of students from the study program, while the fixed costs that must be incurred by the institution cannot be deducted, among others, to pay the basic salary and allowances for permanent lecturers.Besides that, there are difficulties in maintaining the homebase status of lecturers at the time of accreditation, because assessors have a different understanding between the lecturer / student ratio and linearity, where many permanent lecturers fulfill the lecturer / student ratio in 
the study program but when the accreditation assessment is not recognized because it is not considered linear with study programs.

Policies may be require modification (or the establishment), policies fortransformation or development within the organization or outside the organization. The government policy regarding to the appointment of permanent lecturers at private universities, both in the framework of opening new study programs as a minimum requirement for the number of permanent lecturers or in the framework of fulfilling the lecturer / student ratio, is expected to bring a better change to the institution which in this case is PTS in the City and Regency of Cirebon.

The number of students in PTS is not fixed, sometimes it goes up, sometimes it goes down, it really affects the lecturer / student ratio, so the impact that occurs is if a particular study program originally had a large number of students with an ideal ratio,then the following year the number of students becomes slightly while other study programs were initially small in number and then changed to many, so what happened at PTS is the transfer of lecturer homebases to other study programs. The homebase transfer is not only an inconvenience to administration because there must be a process of moving in with the provision of the PT leadership and then loading it to Porlap for changes in lecturer data then being transferred again to the new homebase, it will also have an impact on the lecturer ratio in the first Study Program that will be reduced.Besides that, there are also a number of lecturers who object to being moved home based to another study program, because they already feel that their discipline of knowledge is linear in understanding S1, S2, S3 and then must be transferred to other study programs, although in other programs they can teach courses in accordance with the discipline of knowledge.Another change that occurred in PTS regarding the government policy on the appointment of permanent lecturers is lecturers who teach more professionally because permanent lecturers are lecturers who actually keep teaching in PTS no longer working in other institutions. The government policy on appointing permanent lecturers also motivates lecturers to increase their competence to a higher level, which is S3.

Policies also may be classified asdistributive, redistributive, regulatory, selfregulatory, or emotive-symbolic.Public policy is the policies made by the government as policy makers to achieve certain goals in the community which preparation through process and stages. The policy made by the government regarding the appointment of permanent lecturers at Private Universities must be implemented by all Private Higher Education Organizing Institution (BPPTS).This policy must be used as a guideline as a rule to be obeyed and carried out, because there will be lead sanctions (penalty) for any regulation made but is not implemented.

PTS in the City and Regency of Cirebon has implemented policies and regulations established by the government regarding to the appointment of 
permanent lecturers at PTS, but the government must also consider the condition of the region where PTS is located, because PTS in regions is different from big cities, in regions it is difficult to find permanent lecturers for certain study programs. The government must also consider giving permission to open the same study program at private universities, because it can be a "competitor" that affects the number of students who attend.

The Program. The program is a legitimate way to achieve the goal, where through the approved method the form of the plan will be more organized and easier to implement for the achievement of implementation activities,, because the program has contained various aspects that must be carried out or implemented so that the program's goals can be achieved.Likewise, the implementation of the appointment of permanent lecturer policy on PTS must be supported by an appropriate program so that the process of appointing permanent lecturers in accordance with the assigned provisions.

There are three aspects of the program that support the policy implementation process, namely: a) the intensity of support. The level of support the government provides for the application of policies.b) The source of policy. Is the policy needed to fulfill the needs and demands of the community, or is it designed with little demand and support? c) The scope.Is the policy extensive and comprehensive in scope, or is it concentrated in a narrow geographical scope and subject area?

The Intensity of Support.The level of support carried out by the government for the implementation of the policy of appointing permanent lecturers at private universities is very high, this can be seen from the policies set by the Government, namely through Law Number 14 of 2005 concerning Teachers and Lecturers, Regulation of the Minister of Education and Culture of the Republic of Indonesia number 84 of 2013 concerning the Appointment of Permanent Lecturers of Non Government employees at State Universities and Permanent Lecturers at Private Universities.Furthermore, in the context of fulfilling the lecturer/student ratio, the Government reminded all Higher Education Institutions including Private Institutions to fulfill the lecturer/student ratio and penalty if they did not fulfill the provisions,, through a letter from the Director of Institutional and Collaboration of the Directorate General of Higher Education, Ministry of Education and Culture,then as a solution for Universities to fulfill the lecturer/student ratio, the Government also issued a policy through the Regulation of Minister of Research, Technology and Higher Education of the Republic of Indonesia number 26 of 2015 amended by number 2 of 2016 concerning Educator Registration at Higher Education,in the Ministerial Regulation it is explained that to fulfill the lecturer / student ratio, Universities are given the authority to appoint lecturers with a Special Lecturer Identification Number (NIDK) that comingfrom researchers, practitioners or full-time lecturers. 
Various policies issued by the government towards higher education are a form of government concern in developing higher education in Indonesia.However, even though the policiesare already considered good, there are still weaknesses.Such as NIDK lecturers who are appointed from retirement because to fulfill the lecturer/student ratio, they have to go through a selective process, because usually the one whose retired means old, perhaps in terms of competence has also been reduced.

The Source of Policy.This source of policy is part of the policy implementation process program. This source of policy is needed to fulfill the needs and demands of the community based on requests or support from the community. Therefore, the process of implementing the policy on appointment of permanent lecturers at PTS must also fulfill the needs and demands of the community.In order to meet the demands of the community to make several breakthroughs in various fields, including to improve the quality of human resources lecturers, lecturers are encouraged and assisted to further study to the doctoral level, increasing research activities as well as community service, lecturers must follow and become speakers in national and international seminars, lecturers must write textbooks, write in national and international journals, and also encourage lecturers to improve their functional lecturers.In addition to the quality of human resources, they also improve the facilities and infrastructure to support lectures.However, everything is adjusted to the ability of PTS budgets, because one of the PTS income budgets is from student tuition payments.

The Scope. The scope of the policy is extensive and comprehensive, or is it concentrated in a narrow geographical scope or subject area?The policy on the appointment ofpermanent lecturers at PTS established by the Government is obeyed and implemented by all Higher Education Organizing Institution, not limited by geographical scope or specific area.

The policy on the appointment of permanent lecturers at private University is implemented by all Higher Education Management Institution, whether large or small the institutions, whether the institutions are in the city or in the regions, all must implement it.However, here the government must consider the condition of university in the regions, because Human Resources (HR) in the regions are really limited.

The Images of the Policy.Image is the main goal for an organization, because the image is an impression arising from an understanding of reality.Therefore it is important to consider the image generated by the implementation of policies in the community.

In complying with government regulations in the implementation of policy on appointment of permanent lecturers at PTS not only maintaining PTS image in order to be assessed as a healthy higher education institution, but it is a duty that must be obeyed by all PTS Organizing Institution,, and the perceived impact will be enjoyed by the entire academic community because 
with the number of lecturers fulfilled it will facilitate and ease the mapping of courses and teaching and learning activities, lecturers can get certification and the advantage for the institution is having a competent human resources.

2) The Implementing Organization.The organization is responsible for implementing policies set by the Government.In many cases, this organization is government bureaucratic unit.There are three key variables considered in implementing the policy, namely: a) the structure and personnel $\neg$ the stability of the structure and qualifications of the personnel that must carry out the policy are important things for understanding implementation.An unstable administrative organization and non-qualified personnel will reduce the implementation capacity. b)The leadership of the administrative organization - This variablesimilar to target group leadershiprefers to leadership style and traits. c) The implementing program and capacity - refer to the intensity and accuracy in managing the implementation and general capacity of the organization to fulfill the goals of the program's implementation.

The Structure and Personnel.The stability of the structure and qualifications of personnel as the organization's human resources that must carry out the policy are important to understanding the implementation process or policy implementation. An unstable administrative organization and personnel who are not qualified will reduce capacity in the implementation of the organization's activities.Human Resources is a very important factor that cannot even be removed from an organization.Likewise human resources in PTS cannot be released because human resource is a mobilizer, thinker and planner to achieve the goals of PTS. The existing human resources in the PTS City and Regency of Cirebon have the competence to implement the policy of appointing permanent lecturers according to government regulations,, but the process is adapted to the Standard Operating Procedures (SOP) and policies of each PTS.

The Leadership of the Administrative Organization. Leadership is an ability or strength of someone to influence others in terms of work, where the aim is to achieve the goals of the specified organization.PTS is under the auspices of BPPTS / Foundation, so the final process of appointing permanent lecturers is on the Chair of the Foundation hand.All Foundation Chairmen in PTS City and Regency of Cirebon fully support the implementation of the policy of appointing permanent lecturers, even though the character of each of the foundations varies.

The Implementing Program and Capacity. Program and implementation capacity refers to the intensity and accuracy in managing the organization's general implementation and capacity to fulfill the objectives of program implementation.PTS in City and Regencyof Cirebon have the capacity to examine the minimum number of lecturers and student lecturer ratios, including:1) pay attention to the number of graduates (output) and the 
number of new students (input); 2) prepare lecturer cadres by sending alumni to master level; 3) Utilizing NIDK lecturers.

3) The Target Group. Groups are defined as those who need to adapt new patterns of interaction of a policy.They are the individuals in the organization or group that most affected by policy.It is they who must change to fulfill the demands of the policy.Some relevant factors are:a) the degree of organization or institutionalization of the target group. b) The leadhership of the target group. Leadership can be used as a supporter or opponent of the policy.c) The experience of the target group to the previous policy. The prior policy experience of the target group. Have groups been influenced by government policies in the past?What is the experience and response to government policy?Does it support, oppose, or ignore?

The Degree of Organization or Institutionalization of the Target Group.The level of organization is defined as the degree, position, quality or dignity of the organization which in this case is the PTS in the City and Regency of Cirebon.One indicator in determining the level of PTS is a lecturer, how the condition of the existing lecturers, how the recruitment process, how the competence, and how the ratio with students.

The level and condition of the number of lecturers at PTS in Cirebon City and Regency are:1) strongly influenced by the number of students, because the number of PTS students was fluctuating; 2) As a result of the unstable number of students, the PTS effort is to move the homebase of lecturers from study programs considered to be more lecturers to study programs with less lecturers.3) PTS uses NIDK lecturers, because NIDK lecturers can be turned on and off,4) there are still several study programs that have unideal ratio, because they cannot move homebases from other study programs, so they must appoint new lecturers4) There are some study programs that are no longer active and have no students but are still registered in the Directorate General of Higher Education data. 5) Some students in some certain Study Programs tend to decrease because of limiting job opportunities.

The Leadership of the Target Group. Leadership is the ability of a leader to control, lead, and influence the thoughts, feelings, or behavior of others in achieving predetermined goals.So here leadership can be used as a supporter or opponent of the policy.PTS leaders in the City and Regency of Cirebon strongly support the policy of appointing permanent lecturers in order to fulfill the minimum number of lecturers and fulfillment of lecturer / student ratios, but in their implementation they are adapted to the conditions and abilities of PTS institutions.

The Prior Policy Experience of the Target Group (Target group experience with previous policies). The target group's experience with previous policies becomes a question in the current policy implementation, thereare, has the group been affected by government policies in the past? How is the experience and response to government policy?Does it 
support, oppose, or ignore?Therefore, the experience of the target group on the previous policy becomes a question in analyzing government policy, which in this case is the implementation of the policy on appointment of permanent lecturer at PTS in the City and Regency of Cirebon.

Based on these statements it can be concluded that PTS in the City and Regency of Cirebon carry out the appointment of permanent lecturers are: 1) at the opening of new study program;2) 2) To fulfill the lecturer / student ratio; 3) Large-scale lecturer appointments generally occured around 2015, where in 2015 the Government firmly reminded all state and private universities to fulfill the lecturer/student ratio, because if not they would get warning sanctions, or coaching or deactivation.

4) The Environmental Factors.Factors that can influence or be influenced by the application of policies.Environmental factors can be said as a corridor which prevents the implementation of policies that must be emphasized or even forced.Different types of policies (differing kinds of policy), differences in cultural conditions (differing cultural), social (differing social), politics (differing politics), and economic (differing economic) may apply.

The Differing Kinds of Policy (The difference in police type). The process of implementing the policy on appointment of permanent lecturers at PTS in the City and Regency of Cirebon is adjusted to the policies and Standard Operating Procedures (SOPs) of each PTS and the important is not contrary to the government regulations.

The Differing Cultural (Different types of culture).Culture is a way of life that develops, and is owned together by a group of people and is passed down from generation to generation.In the process of implementing the policy on appointing permanent lecturers at PTS in the City and Regency of Cirebon, this cannot be separated from the cultural factors of society, namely the Javanese community because the community of Cirebon City and

Regency are Javanese.One of the cultures that exist in the Javanese is the philosophy of life

"mangan ora mangan waton kumpul" (the most important is gathering whether eating or not eating). This kind of culture is indirectly passed down from generation to generation by the Javanese community even until today it still.Such culture is also a consideration of PTS in the City of Cirebon in appointing permanent lecturers, among them is happens at PTS in the City and Regency of Cirebon, where there are some lecturer applicants give reason "want to be close to parents", "want to get closer or together with husband / family", although financially at the previous workplace it would have been much greater.

The Differing Social (Differences in social types). Differences in social types occur anywhere and anytime, including in the City and Regency of Cirebon.This social type shows that social status, where social status is a person's position in the community that can be obtained automatically 
(automatically) through business or because of gift.Social interaction encourages individuals to achieve higher social status. Higher social status will also affect on attitudes and a high sense of respect in society. Therefore, everyone will try to achieve a higher social status.Lecturer status is a status that is considered very valuable in the communityeyes, it has a high prestige value, that's why so many people want to become lecturers.Lecturer status is considered as pride, it is also considered valuable and dignified so that's why it is respected by many people.

The Differing Politcal (different types of politics). Politics is the process of forming and sharing power in a society which, among others, is in the form of a decision making process. And one of the goals of politics is to try for power in society and government to be obtained, managed and applied in accordance with applicable norms and laws.Policy of appointment of permanent lecturers at PTS is a political decision that must be implemented in the administrative process, that is, it must be implemented by all Higher Education Organizing Institution (BPPT)

The Differing Economic (Different types of Economy). Humans as social beings basically always face economic problems, where the core of this economic problem is the fact that human needs are unlimited, while the instrument of satisfying human needs is limited.Economic factors influence public interest to become a lecturer, many of them applied to become lecturers at PTS in Cirebon City and Regency.In addition to the government's policy of providing certification.So the lecturer has something promising, beecome an idol, people like to be called Mr / Mrs.

\section{Efforts done by Private Universities in the City and Regency of Cirebon to appoint permanent lecturers \\ The efforts done by private universities in Cirebon city and regency to appoint permanent lecturers are as follows:}

\section{1) Lecturer Intensification}

Lecturer is professional educator and scientist whose main task is to transform, develop, and distibute knowledge and technology through education, research, and community service.

Lecturer intensification is the use of existing lecturers ashuman resources of PTS in order to fulfill the minimum number of lecturer requirements and fulfill the lecturer/student ratio. The minimum number of lecturers for each study program is 6 (six) people and the lecturer ratio for the Natural Sciences program is 1: 30 and for the Social Studies program for 1: 45.This intensification is done by: a. Move the lecturer homebase

The number of students in PTS is not fixed, sometime it goes up, and sometime it goes down. This number of students condition (goes up and down) is very influential on the ratio of lecturers / students, so the impact that occurs is if a particular study program originally had a large number of students with 
an ideal ratio, then the following year the number of students islittle while other study programs are initially little in number of students and then changed to many, so that happened at PTS is the transfer of lecturer homebases to other study programs.

b. Encourage lecturers to continue their studies to a higher doctoral level and improve the Lecturer Functional Position

In order to better guarantee the quality of lecturers at PTS, PTS in the City and Regency of Cirebon encourages lecturers to improve their competencies among others encouraging lecturers to further their doctoral studies with the help of scholarships from institutions or scholarships from the government. Also encourage and assist lecturers to improve functional positions from teaching staff to expert assistants, from expert assistants to lectors, from lectors to chief lectors, and from chief lectors to professors.

\section{2) Lecturer Extensification}

Lecturer extensification is a strategic step taken by PTS to fulfill the minimum number of lecturers and fulfillment of lecturer / student ratio.To appoint lecturers PTS divide into 3 (three) conditions, there are: 1) to fulfill the minimum requirements of the number of lecturers, 2) to fulfill the lecturer / student ratio,3) to strengthen human-lecturer resources in order to improve the quality of education and increase the value and level of accreditation both in the accreditation of study programs and accreditation of institutions.

\section{An effective strategy to optimize the implementation of the policy on appointment of Permanent Lecturers at Private Universities in the City and Regency of Cirebon}

The strategy used to optimize the implementation of the policy on appointment of permanent lecturers at PTS in Cirebon City and Regency is to use a qualitative SWOT analysis, It is by utilizing the strengths owned and opportunities faced to overcome the weaknesses that are owned and anticipate threats (threats) faced, namely:

1. PTS determines SOP regarding acceptance of permanent lecturers, both NIDN and NIDK lecturers, based on Government Regulations

2. To fulfill the Lecturer / Student ratio or the minimum requirements for opening a New Study Program, PTS accepts applications for prospective lecturers and selects applicants who have the competency to become Permanent Lecturers, both NIDN and NIDK.

3. In the appointment of permanent lecturers both NIDN and NIDK, PTS still maintains budget capability, because the source of PTS revenue is only from receiving student tuition

4. PTS Build partnerships and cooperation with high schools and Government / Private Agencies to attract the number of students received.

5. In opening the new Study Program, BPPTS and PTS consider the Lecturer human resources owned and other PTS conditions, because other PTS 
which has the same Study Program will indirectly become a good competitor in accepting lecturers and accepting students.

6. PTS involves students in all Higher Education Tri Dharma activities, so students become qualified graduates who are needed in the working world.Thus the image of PTS will be better and desirable by prospective students and prospective lecturers.

\section{Novelty Research}

Besides of those factors, researchers also found other factors that influence the implementation of policy on appointment of permanent lecturer at PTS in Cirebon City and Regency, namely:

a. Organizational culture is different between PTS in the City and Regency of Cirebon with State Universities (PTN) and PTS in other regions.This causes differences in the views, values, norms, orientation, attitudes and behavior of each.

- The number of students who enter PTS in general is not fixed, sometimes it goes up sometimes it goes down, so it affects the lecturer / student ratio.

- $\quad$ Rise and fall of the number of students greatly affect the ability of PTS budget, because the source of PTS income is from the acceptance of student tuition.So this is a consideration for PTS in the appointment of permanent lecturers.

- The PTS management autonomy is regulated by the Organizer Agency in accordance with statutory regulations.So the SOP for the appointment of permanent lecturers at PTS varies according to the policies of each BPPTS.

b. Motivation which is the reason and underlying actions done by someone to become a permanent lecturer at PTS in the Cirebon City and Regency, namely:

- The religious factor is a strength that is believed in determining the way of life and influencing human life, so this religion is a belief, where there are some practitioners who move to lecturers, because the job of being a lecturer is considered as a noble work.

- Psychological factors study the behavior of permanent lecturers at PTS in Cirebon

City and Regency, both as individuals and in relations with their environment.Some Permanent Lecturers at PTS in the City and Regency of Cirebon get an inner satisfaction feeling when they teach, because of their status as a lecturer, although they receive a small salary as a lecturer from their work, it is not such a problem for them. Besides that, there is also the pride of being a lecturer, because the lecturer is a status that is considered very valuable in the community eyes, it has a high prestige value, so many peoplewant to become lecturers.Lecturer status 
is considered as pride, it is considered precious and dignified so that many people will respect.Psychological factors also occur because of emotional feeling with the teaching staff,it is all because they have taught too long and served in private universities, so they are appointed as permanent lecturers with NIDN or NIDK status even though they are still in service in other agencies or civil government employee's status.

c. Competitiveness, there are: 1 ) Other PTS around the City and Regency of Cirebon that have the same Study program which is considered as a "competitor",2) Senior High Schools or government and private institutions as a source of prospective students, and 3) organizations / institutions that absorb PTS graduates.

- $\quad$ Other PTS that are around the City and Regency of Cirebon that have the same Study program have an impact on the number of students who joint to PTS.

- To collaborate with high school or government and private institutions to attract the number of students.

- Job opportunities for PTS graduate in government / private organizations / agencies have an impact on prospective students to enter PTS.

The number of students who enter PTS will have an impact on the fulfillment of permanent lecturers at PTS.

\section{Analysis of the Effectiveness of PTS Organizations in Cirebon City and Regency in the Implementation of Policy on Appointment of Permanent Lecturers at Private Universities}

Analysis of the implementation of the policy on appointment of permanent lecturers at PTS in the City and Regency of Cirebon which has been analyzed by Smith's theory (1973), then analyzed with the theory of organizational effectiveness that is to find out whether PTS, in this case as an organization in the field of Higher Education, has been effective or not in implemented in the appointment of permanent lecturers.The theory of organizational effectiveness used as material for analysis is the theory of Gibson at.al. (1993) consisting of production, efficiency, satisfaction, adaptation and development.

1) Production. Production at PTS reflects PTS ability to produce the amount and quality of output needed by the environment, which includes receiving tuition received from students to fulfill the activities of the Tri Dharma College and produce graduates who are needed by the world of work.

PTS in the City and Regency of Cirebon as a non-profit organization moved in education really strives to create quality graduates who are qualified in addition to have competence in their respective fields of knowledge also 
have other expertise that is truly as a necessity of the community.However, all these efforts depend on the ability of each PTS organization.

2) The Efficiency. The efficiency program at PTS focuses attention on the overall cycle of input-process-output, by emphasizing how much tuition fees are charged to students, so that PTS acceptance from tuition fees costs to finance the activities of the Tri Dharma of University namely the Research Education and Community Service activities.Including in this activities are to fulfill the needs of lecturers, to fulfill the minimum amount and to fulfill the lecturer / student ratio. Theincome source of PTS in the City and Regency of Cirebon is really from the payment of student tuition fees, so if it get a lot of students automatically PTS income that used to finance The Tri Dharma University activities increases, but vice versa.Therefore PTS is always trying to be efficient in the use of budgets,among them, for lecturers' acceptance either NIDN or NIDK Lecturers which in this case are to fulfill the minimum lecturer requirements and to fulfill lecturer / student ratios, which is very dependent on the ability of the budget that is from the reception of tuition.

3) Satisfaction. Satisfaction and morals of PTS are showing the level where PTS as an organization moved in the Higher Education sector fulfill the needs of its employees both educators (lecturers) and students and students.The income received from the payment of student tuition fees is a source of PTS to hold activities of Tri Dharma University so as to provide satisfaction to its employees both educators (lecturers) and students and students. PTS has provided compensation in the form of the right to work and its service as a lecturer in accordance with the capabilities of the institution, As for the problem of satisfaction and dissatisfaction are relative, because based on that opinion it is also seen that there are some lecturers who devote themselves to become lecturers because of psychology factors, they become lecturers because they love teaching, they are satisfied to be lecturers, they can share their hearts and share knowledge.

4) Adaptation. Adaptation is the level at which an organization can and truly responds to internal and external changes.This adaptation refers to the ability of management to feel the need for changes in the environment, including changes in the body of the organization itself.Therefore, PTS as an organization must be able to adapt to internal and external changes, so that PTS can run well and smoothly in carrying out the Tri Dharma of University activities. PTS in the City and Regency of Cirebon, especially regarding the fulfillment of the minimum number of lecturers and the fulfillment of Lecturer / Student ratio, always adapts and adjusts to government regulations, among the PTS principles is "if you want to exist, follow the rules of Dikti(kalau ingin eksis ikuti aturan Dikti)".

5) Development. An organization must make various efforts to increase the chances of long-term survival.The development efforts undertaken by PTS 
in Higher Education Tri Dahrma activities are to improve the quality of lecturers by increasing further studies to higher levels (S2 to S3), increasing research activities, and increasing community service activities.Furthermore, it also increases the activities of student organizations, increasing the quality of graduates so that they are easily accepted in the world of work, which in turn increases the level of accreditation both in the Study Program and institutional accreditation.The better accreditation ranking will increase the interest of students and lecturers who want to join PTS, so PTS continues to grow. Private universities in Cirebon City and Regency always develop their institutions so that institutions still exist and grow up by always obeying the rules set by the government.Various efforts were made to develop the institution including improving the quality of lecturers through increasing further study to higher educations (S2 to S3), increasing research activities, and increasing community service activities, thus expected lecturers to become more qualified and be able to produce qualified graduates, so the institution willgrow up more. Based on the description above, the relationship of the results of the research with the modification of the theories of Smith (1973) and Gibson (1993) described above, can be seen in the following figure: 


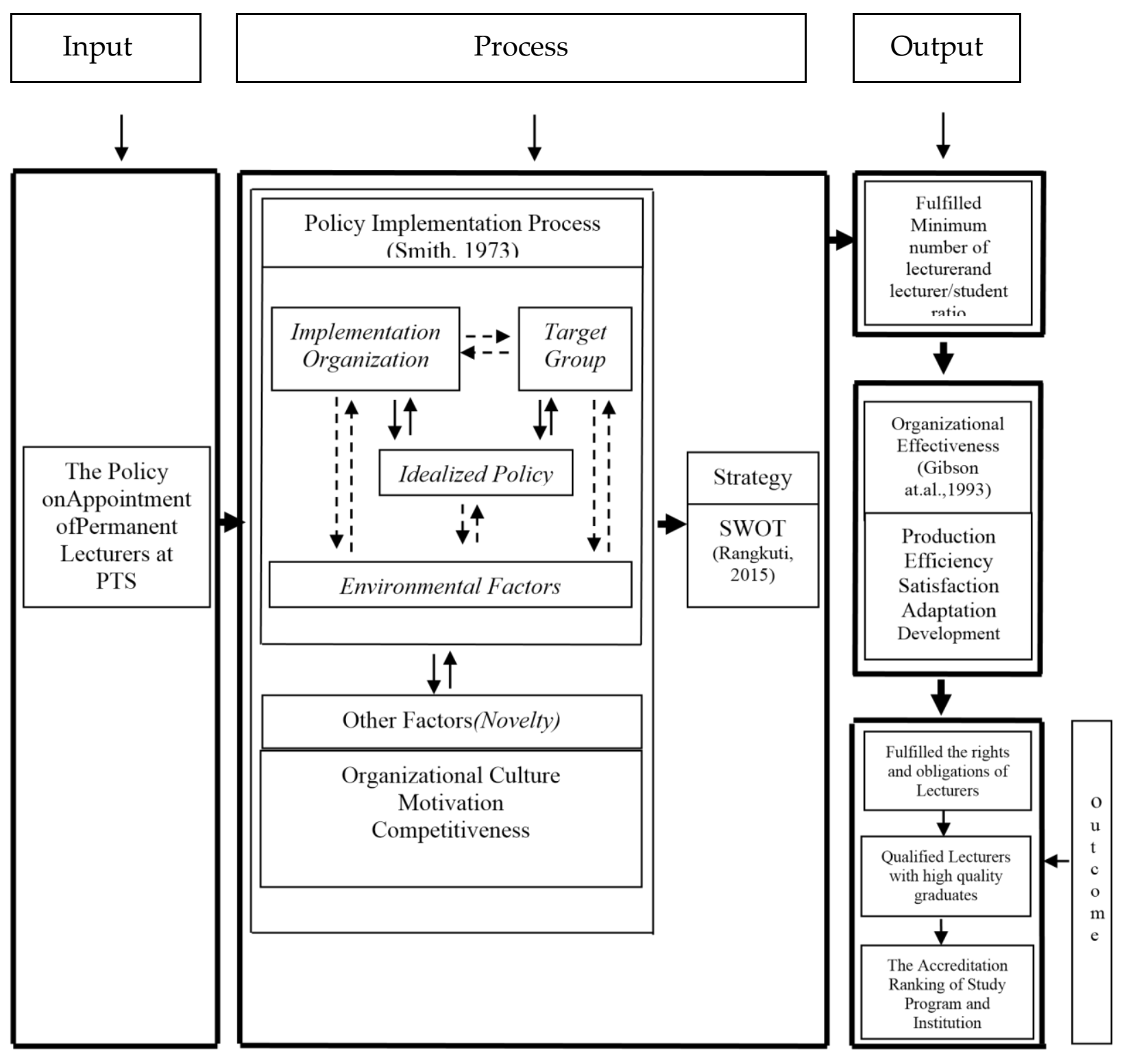

Figure 2

Relationship between Modified Research Results with Smith and Gibson's Theories

The essence of the relationship between the modification of the Research Results with Smith and Gibson's Theory in the Implemetation Policy on Appointment of Permanent Lecturers at Private Universities in the City and District of Cirebon is as follows:

a. PTS in the City and Regency of Cirebon implement a policy on appointment of permanent lecturers.

b. The appointment of lecturers is still carried out in the framework of: 1) to fulfill the minimum requirements for the number of lecturers, 2) to fulfill 
the lecturer / student ratio, 3) to strengthen human-lecturer resources in order to improve the quality of education and increase the value and level of accreditation both in the accreditation of study programs and institutional accreditation.

c. The important components in the process of implementing permanent lecturer appointment policy at PTS in Cirebon City and Regency are: 1) idealized policy, 2) the implementing organization, 3) the target group and 4) environmental factors.

d. Besides those 4 (four) components, there are also other factors that influence the implementation onappointment of permanent lecturer policy, namely: 1) Organizational Culture, 2) Motivation, and 3) Micro External Environment.

e. The strategy used to optimize the implementation of the policy for appointment of permanent lecturers at PTS in Cirebon City and Regency is a qualitative SWOT analysis, namely by utilizing the strengths owned and opportunities faced to overcome the weaknesses owned and anticipatesthreats faced.

f. Implementation of the policy on appointment of permanent lecturers is expected to meet the minimum number of lecturers and lecturer / student ratios.

g. Input-Process-Output is then analyzed with the theory of organizational effectiveness, it is finding out whether PTS as an organization in the field of Higher Education has been effective or not yet in the implementation of permanent lecturer appointment policy.So that it is expected to have an impact on fulfilling the rights and obligations of lecturers, producing quality graduates, and finally obtaining the maximum value of accreditation of study programs and institutions.

\section{CONCLUSION}

Based on the results of the discussion above, the following conclusions can be drawn:

1. The factors causing the unoptimal of implementation of the policy on appointment of permanentlecturers at PTS in the City and Regency of Cirebon,based on the theoretical approach to the implementation of Smith's policy process (1973) and based on research findings that optimizing the appointment of permanent lecturers at Private Universities in the City and District of Cirebon can be achieved if organizational culture factors, motivation, and micro external environment are developed.

2. The efforts done to implement the policy of appoint permanent lecturers at private universities in Cirebon city and regency are carried out through lecturer Intensification and Extensification. Lecturer intensification includes: Moving lecturer homebases and Encouraging lecturers to continue their studies to a higher level of S3 and improving Lecturer 
Functional Position.While lecturer extensification includes 1) fulfilling the minimum number of lecturers, 2) fulfilling the lecturer / student ratio, 3) to strengthen human resources-lecturers in order to improve the quality of education and increase the value and level of accreditation both accreditation of study programs and accreditation of institutions.

3. The strategy of implementing policies on the appointment of permanent lecturers at PTS in Cirebon City and Regency by SWOT analysis based on logic that can maximize Strength and Opportunity, while simultaneously minimizing Weakness and Threat.Effective strategies to optimize the implementation of the policy in appointing permanent lecturers at PTS in Cirebon City and Regency are: 1) PTS determines SOP regarding acceptance of permanent lecturers, both NIDN and NIDK lecturers, based on Government Regulations,2) To fulfill the Lecturer / Student ratio or the minimum requirements for opening a New Study Program, PTS accepts applications for prospective lecturers and selects applicants who have the competency to become Permanent Lecturers, both NIDN and NIDK, 3) In the appointment of Permanent Lecturers both NIDN and NIDK, PTS still maintains the ability of the budget, because the income source of PTS is only from receiving student tuition,4) PTS Build partnerships and cooperation with high schools and Government / Private agencies to attract the number of students who will join,5) In opening the new Study Program, BPPTS and PTS considered the Lecturer human resources owned and other PTS conditions.Because other PTS which has the same Study Program will indirectly become a competitor both in the acceptance of lecturers and student receptions, 6) PTS involves students in all Higher Education Tri Dharma activities, so students become the qualified graduates needed in the world of work. Thus the image of PTS will be better and desirable by prospective students and prospective lecturers. 


\section{REFERENCES}

1. Anderson, James E, 1979, Public Policy Making, New York, Holt Rinchart and Winston.

2. Arwildayanto, 2013, Manajemen Sumber Daya Manusia Perguruan Tinggi, Bandung, Alfabeta.

3. Creswel, John W, 2014, Research Design, Pendekatan Kualitatif, Kuantitatif, dan Mixed, Yogyakarta, Pustaka Pelajar.

4. Denhart, Janet V. et.al., 1998, Public Administration for the Twenty-First Century. Fort Wort : Harcourt Brace \& Company.

5. Dunn, William N, 2006, Pengantar Analisis Kebijakan Publik, New York : Englwood Cliff, Prentice Hall.

6. Dwijowijoto, Riant Nugroho, 2007, Kebijakan Publik, Formulasi, Implementasi dan Evaluasi. Jakarta : Elex Media Komputindo.

7. Edward III, George, 1980, Implementing Public Policy. Washington DC, Congresional Quartely Press.

8. Gibson at.al.1997, Organisasi dan Manajemen.Jakarta, Erlangga.

9. ---------------, 1993, Organisasi, Perilaku Struktur Proses. Jakarta, Erlangga.

10. Grindle , S Marrile, 1980, Politics and Policy Implementation in The Third Word,. New Jersey : Princeton University Press.

11. Ivancevich, John M. at.al, 2006.Perilaku dan Manajemen Organisasi.Jakarta, Erlangga.

12. Mazmanian, Daniel A, and Paul A, Sabatier. 1983, Implementation and Public Policy, Grenvies Ilinoiw Scott, Foreman and Company.

13. Maleong, Lexy J., 2013. Metode Penelitian Kualitatif, Bandung, Rosdakarya.

14. Miles, Matthew B \& Michael A. Huberman, 1992.Qualitative Data Analysis : A Sourcebook of New Method. London. Sage Publication.

15. Nugroho, Riant, 2004, Public Policy :Formulasi, Implementasi dan Evalauasi. Jakarta, Elex Media Computindo

16. Rangkuti, Freddy. 2015, SWOT Balanced Scorecard..Jakarta : PT Gramedia Pustaka Utama.

17. Robbins, Stephen P, 1996, Organizational Behavioer, New Jerresy Prentice Hall, INc A Simon \& Schuisher Company, Englewood Cliffs.

18. Smith, Thomas B. 1973. The Policy Implementation Process.Springer.

19. Sters, M. Richard, 1985, Efktivitas Organisasi. Jakarta, PT Erlangga

20. Steers, Richard M, 1997, Organizational Effectiveness, A. Behavioral View.Santa Monica California : Goodyear Publishing Company Inc.

21. Van Meter, Van Horn, 1975, A Model of The Policy Implementation. Post Washington, Publishing Co, Ind.

22. Waldo, Dwight, 1972, Public Administration in a Tiem of Turbulence, San Fransiso, Chendler. 
23. Westra, Priata dkk.1999, Ensiklopedi Administrasi, Jakarta, Haji Masagung.

24. White, Leonard D, 1955, Introduction of Studi of Public Administration. New York, The Ma Millan Company.

25 . The 1945 Constitution of the Republic of Indonesia.

26. Law Number 14 of 2005 concerning Teachers and Lecturers.

27. Law Number 12 of 2012 concerning Higher Education.

28. Law Number 4 of 2014 concerning Implementation of Higher Education and Management of Higher Education. 